$1-2007$

\title{
Citizens of Memory: Refiguring the Past in Post-Dictatorship Argentina
}

Silvia Tandeciarz

College of William \& Mary, srtand@wm.edu

Follow this and additional works at: https://scholarworks.wm.edu/aspubs

Part of the Modern Languages Commons

\section{Recommended Citation}

Tandeciarz, Silvia, Citizens of Memory: Refiguring the Past in Post-Dictatorship Argentina (2007). PMLA, 122(1), 151-169.

https://doi.org/10.1632/pmla.2007.122.1.151

This Article is brought to you for free and open access by the Arts and Sciences at W\&M ScholarWorks. It has been accepted for inclusion in Arts \& Sciences Articles by an authorized administrator of W\&M ScholarWorks. For more information, please contact scholarworks@wm.edu. 
122,1

\title{
Citizens of Memory: Refiguring the Past in Postdictatorship Argentina
}

\author{
SILVIA R.TANDECIARZ
}

SILVIA R TANDECIARZ is associate professor of Hispanic studies at the College. of William and Mary A cultural studies specialist, she has published numerous articles in scholarly journals as well as translations of poetry and criticism This essay is part of a larger project on memory and visual culture in postdictatorship Argentina
A RGENTINA'S URBAN LANDSCAPE HAS UNDERGONE A REMARKable transformation in the last decade The political, social, and economic turbulence that marked the country's passage to the twenty-first century has helped to transform its cities, unear thing a history of repression buried by the democratic state since 1986 as a precondition for stability and economic growth. Nowhere is this shift more striking than in Buenos Aires, the nation's symbolic center, one of many places where new social actors are working to ensure that the brutal dictatorship that convulsed Argentina between 1976 and 1983 is not forgotten. Mapping the work of cultural memory onto the Buenos Aires cityscape through the creation of "lieux de memoire," or sites of memory (Nora), ordinary citizens are helping to shape a new collective imaginary. Their initiatives evoke Gustavo Remedi's obser vation that "[1]a posibilidad de la memoria reside en la posibilidad de la ciudadanía, y esta última depende de una ciudad que la acoja, que la cultive, que la haga posible" ' $[t]$ he possibility of memory resides in the possibility of citizenship, and the latter depends on a city that welcomes it, that cultivates it, that makes it possible' (365) ${ }^{1}$ In analyzing some of the public memorials erected in Buenos Aires to honor the victims of state terrorism, I seek to show how geography, architecture, trauma, and memory interface today in the rearticulation of an Argentine national identity.

As is widely known, the military junta that ruled the country in the late seventies and early eighties implemented a regime of tex ror that resulted in the illegal detention, torture, and death in clandestine concentration camps of thousands of Argentine citizens Approximately nine thousand cases were documented in Nunca más: Informe de la Comisión Nacional sobre la Desaparición de Personas (1984), but

[C 2007 BX XHE MODERN I ANGUAGE ASSOCIATYON OF AMERICA]

151 
human rights organizations estimate the total number of victims at thirty thousand, many of whom remain unaccounted for to date While institutional attempts were made in the dictatorship's immediate aftermath to try those responsible for crimes against humanity, the Due Obedience and Punto Final 'Final Point' legislation passed in 1986 effectively ended the process of bringing those responsible to justice. The decade that followed was dominated by politicas de olvido 'politics of forgetting'including the amnesty granted those military officials who had been sentenced before 1986-which the state pursued in the name of national security, economic stability, and progress Adolfo Scilingo's 1995 public confession regarding his participation in the infamous death flights proved a first turning point in the discour se of memory; the process of resignifying the past it accelerated reached maximum visibility with Argentina's 2001 financial and institutional collapse, which in turn set the stage for the effusive er uption of memor y we witness today in the Buenos Aires cityscape. ${ }^{2}$

While an impressive body of scholar ship is dedicated to postdictatorship cultural production, relatively little work has been done on the material spatialization of memory nat ratives in Argentina ${ }^{3}$ In recent years, this has begun to change, partially because of a perceived exhaustion of discursive register's capable of narrativizing trauma and partially because of the impor tant confluence of social movements and cultural production catalyzed by the inadequacy of the democratic state's institutional response. Motivated by the juridical vacuum in which the democratic process floundered for almost two decades (Jelin and Kaufman 93), new historical actors have emerged, driving the work of memory into the public sphere through extramural, grassroots movements ${ }^{4}$ L eading this process have been human rights organizations, neighborhood assemblies, and art collectives that have turned city streets into their canvas, reinvigor ating not only the work of memory through their art actions but also that of cultural studies practitioners, who have begun to take notice. ${ }^{5}$

Consonant with this shift, my own study of commemorative sites takes as its point of departure the assumption that "memory is made of 'facilitations' . . .. dense significations, figures and scenes that establish points of condensation and anchorage with respect to the past and forge exemplary values, which are not given once and for all but require constant reworking and reinforcement from the present" (Vezetti 166). The memorial sites this essay discusses-the Parque de la Memoria and the excavated clandestine detention center Club Atlético-function as two such "points of condensation" Products of grassroots organizing and recent legislative actions, they facilitate and reflect contemporary states of memory while providing useful analytic frameworks that advance our under standing of collective cultural responses to the shortcomings of representative democracy

In the pages that follow, I examine the kinds of recollection current reconfigur ations of spatial relations map, and I explore how histories buried for the last quarter of a century are resurfacing in contemporary Buenos Aires, affecting the constitution of new historical subjects through a practice of everyday life As I trace the memory effects articulated by the Parque de la Memoria and the Atlético, I hypothesize that the work of recollection they perform in transfor ming the city's public sphere-as collabor ative, community-driven, and state-sponsored initiatives-will lead to a transformation in the performance of citizenship that the city either facilitates or blocks Because each historical subject is also the product of the paths he or she has chosen, changes in the landscape can help shape new forms of civic engagement. How individuals in habit this geography, which routes they choose, and what they encounter along the way can have profound consequences for the construction of their subjectivities and the at ticulation of civil society. Although different in their tone, ex- 
ecution, and reach, in their current configurations both memorials prove excellent vehicles for studying how a new imagined community is being constituted and for tracing some of the growing pains associated with its metamorphosis. As the tensions evident at both sites suggest, it is in the uneasy coexistence of past and present, in the rub of dissonant discourses, and in the open and continuing dialogue those discourses promote that a new Argentine citizenry is being forged.

\section{Parque de la Memoria}

The city will doubtlessly change when the riverbanks are marked by a twenty-hectare public park with seventeen monumental sculptures and an artificial hillside with an open wound cutting across its territory, punctuated with thousands of names of Argentines killed by state terrorism It will also change to the extent that a progressive political project takes shape and becomes capable of channeling all the city's cultural and human potential

-Marcelo Brodsky, Nexo (123-24)

The constr uction of a memory park dedicated to the victims of state terrorism on fourteen hectares along the coast of the Río de la Plata, between the nor theastern corner of the Ciudad Universitaria (University of Buenos Aires campus) and the Costanera Norte, was approved by the legislature of Buenos Aires on 21 July 1998 The park was inauguratedalbeit still undex construction-nine months later on the twenty-third anniversary of the coup. ${ }^{6}$ Although its out-of-the-way location has been critiqued as mar ginalizing the memory of a national trauma, which should have taken center stage in the city's gover nment or business districts, the site remains significant in several ways: its proximity to the river marks where thousands of the disappeared met their end through the infamous death flights; its proximity to the university reminds visitors of one institution with which many of the victims were associated, of dreams and life projects cut short; and its proximity to the Escuela Superior de Mecánica de la Armada (ESMA [Navy Mechanics' School]) signals where perhaps the most notorious clandestine detention center functioned When finished, it will include a monument to the victims of state terrorism designed by the Baudizzone, Lestard, Varas Studio and the associated architects Claudio Ferrari and Daniel Becker; a sculpture park; memorials to those killed in the 1994 terrorist attack against the Asociación Mutual Israelita Argentina and to "the just among nations" (individuals who helped Jews duxing the Holocaust); and a center for the promotion of education, research, and memory. While each of these elements represents memory initiatives equally worthy of recollection, I submit that they do not necessarily work well together Separately conceived according to divergent aesthetic principles, they seem awkward in juxtaposition even at this early stage. It is this tension generated between them-beyond the statements each of its components makes - that interests me here, a tension I read as representative of the fraught nature of recollection and the persistent difficulty of consensus in Argentina regarding the dictatorship years

One of the park's most evocative features today (if a transitory one) is its unfinished state, teminding its visitors that this memory is still in the making, still raw-the opposite of a "finished monument [that] would, in effect, finish memory itself" (Young 194). The fences that surround and protect it, the noise of planes flying overhead, the sense of being exposed to the elements and enclosed by barbed wire, the tall lights that echo prison lights and evoke a sense of surveillance are all conducive to the feeling of being shipwrecked, unmoored, voided of identity They suggest a wasteland-a moral and ethical defeat constitutive of the present The voiding of identity suggested by the park's ambience is echoed in the Monumento a las Víctimas del T'er ror ismo de Estado: 
The monument cuts deep like a wound or a scar into the elevated grassy surface of the park that faces the river in the half round Visitors will enter the monument underground from the city side of the wall, and move through the zig-zag structure until they are released toward the river and the shoreline walkway. The overall design is classically modernist in its geometric configuration and felicitously minimalist in its lack of ornamentation and monumental ambition

(Huyssen 16)

Because it is conceived as a gash in a barren landscape-lined by four noncontinuous walls bearing the names of the disappeared and including spaces for the addition of those not yet identified ${ }^{7}$-this monument echoes the gestures of Holocaust memorials in the countermonument tradition, where " $\mathrm{t}]$ he most important 'space of memory' " has not been the space in the ground or above it but the space between the memorial and the viewer, between the viewer and his or her own memory: the place of the memorial in the viewer's mind, heart, and conscience" (Young 118). As James Young notes, "In the cases of disappearing, invisible, and other countermonuments, they have attempted to build into these spaces the capacity for changing memory, places where every new gener ation will find its own significance in this past" (119) Instead of projecting a finished accounting that towers over the landscape, the Monument to the Victims of State Terrorism mater ializes a xift in history, a cavity retreating into negative space that reminds visitors both of its hidden, underground dimension and of the intimate buxden of xecollection it places on each of them Ripping open the ground beneath their feet, it exposes Argentina's flawed foundation and reveals an open wound festering in the collective imaginary.

While the nonmonumental quality of the design complements the memory it honors, it is less clear how the remaining elements planned for the park inter act with this gesture. Most at odds with the monument's design are the eighteen sculptures commemorating the victims of repression, not because of what they represent but rather because their presence competes with the kind of self-reflection the monument encourages, risking the very aestheticizing of traumatic memory the monument evades The multisculptural complex was specified by the 1998 law approving the park's construction, in the same article calling for a monument. More than six hundred sculptors submitted works in response to the inter national call issued by the park's planning commission (Comisión Pro Monumento a las Víctimàs del Ter ror ismo de Estado); these were then judged by a jury of ar tists, curators, and human rights activists charged with selecting the winning entries on the basis of "a series of ethic[al] and aesthetic principles coherent with the Park's purpose of keeping alive the memory towards the future" ("Art") ${ }^{8}$ In addition to the twelve projects chosen, six were commissioned from well-known artists committed to human rights.. Together these sculptures xepresent works from nine countries and add a global dimension to the park. Among the more compelling arguments supporting their integration is that they reflect the planetary reach of "contemporary memory culture" (Huyssen 15) while articulating the specificity of the local exper ience. As Andreas Huyssen states:

We are remembering students and workers, women and men, ordinary people who had a social vision at odds with that of the ruling elites and the military, a vision shared by many young people across the globe at that time, but which led to imprisonment, torture, rape, and death only in a few countries of the world. Thus the monument becomes part of the global legacy of 1968, perhaps its darkest and most tragic part

$(16-17)$

This legacy explains the commission's decision not only to issue an international call for sculptures but also to include cultural responses from outside the national exper ience 
inspixed by that lost generation of 1968 . By placing this memory in a global context, moreover, the planning commission recognized the vital role the international movement for human rights played in accelerating the end of the dictatorship and in further ing the process of bringing those responsible to justice.

It is difficult to quar rel with the memory work the completed multisculptural complex will perform But, as I suggest above, from another critical perspective it is equally difficult to deny that the sculptures manifest a kind of excess: an excess of memory because of their potential associations with other places and other times and because of the explicitness of their languages, their acute narrativization of trauma-they are exercises in witnessing meant to model, as secondary witnesses, the kind of memory work the park as a whole would encourage ${ }^{10}$ Whether intended to attract more visitors to the park, including tourists interested in postmodern art, or to condense a series of reflections on repression addressed to a local population while also serving as international human rights manifestos-part of what Florencia Battiti calls "la influencia globalizadora de la 'memoriamanía' inter nacional" "the globalizing influence of an international "memorymania" (56)-the sculptures risk contributing to the very institutionalization of memory that is conducive to forgetting Juxtaposed to the monument's minimalist design, they present a problemdisturbances in the field that disr upt the park's other wise rather straightforward grammar

Nowhere is this tension clearer than in the Plaza de Acceso (fig 1), completed six years after the park's inauguration with the
FIG. 1

The Plaza de Acceso in the Parque de la Memoria

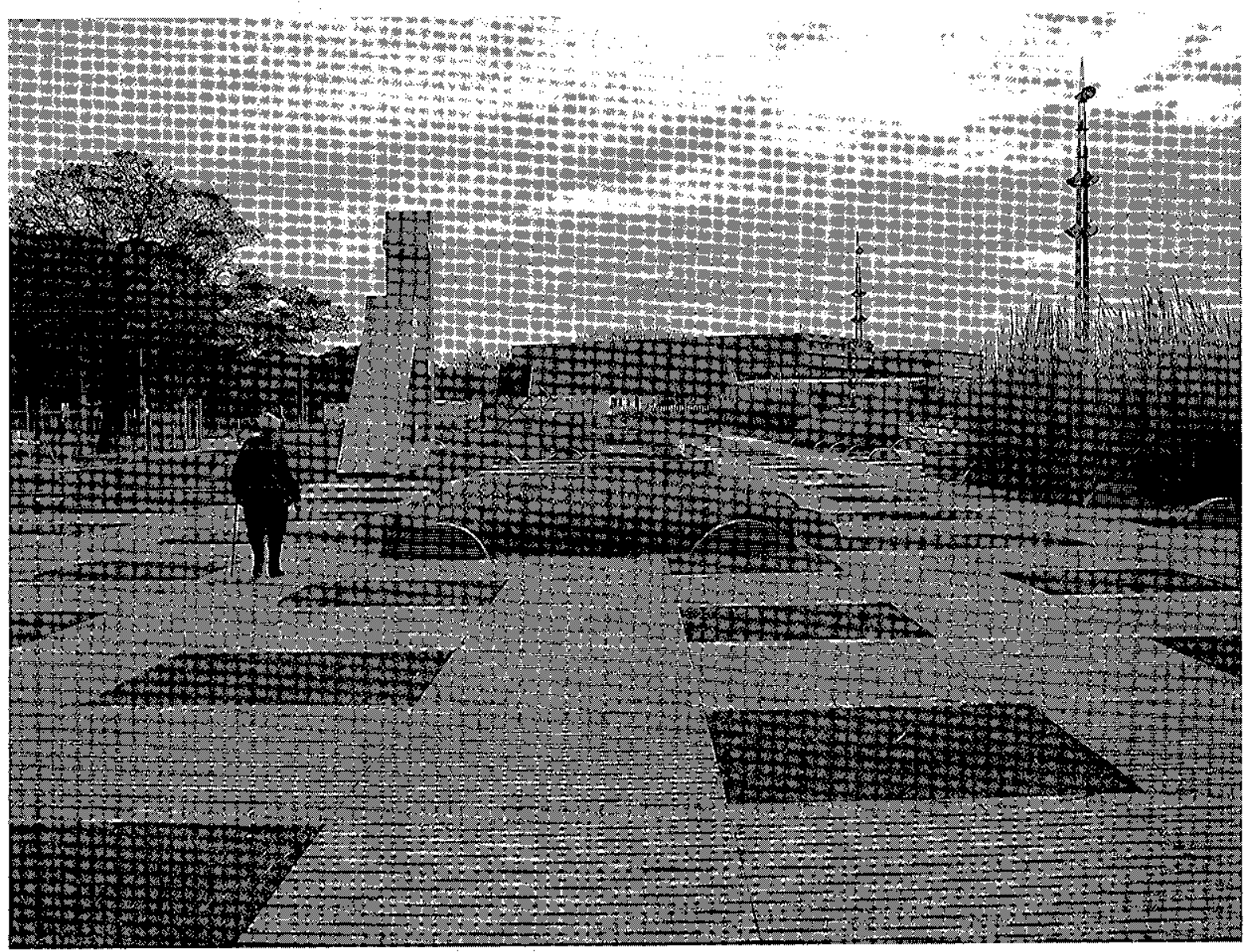


installation of three massive sculptures (figs 2-4): Dennis Oppenheim's Monumento al escape (Monument to Escape), William Tucker's Victoria (Victory), and Roberto Aizenberg's Sin título (Untitled). Honoring primarily an abstract resistance to the system of state terrorism, the sculpture by Oppenheim mirrors this system's totalitarian face with the distorted replica of a prison turned upside down, repeating its repressive structure to question and undo it Iucker's is, perhaps, the vaguest of the three, proclaiming a victory, in the shape of the letter $V$, yet to be felt by all those still trapped in the dictator ship's shadow And Aizenberg's invokes the ghostly presence of those taken,

Fig. 2 mapping a desire to remember their utopian Monumento al vision onto a horizon that, postdictatorship, escape (Monument still threatens to obliterate them Of the three, to Escape), by only Aizenberg's was commissioned for the Dennis Oppenheim,. park and produced by an Argentine sculptor; in the Parque de himself a victim of repression, his partner's la Memoria

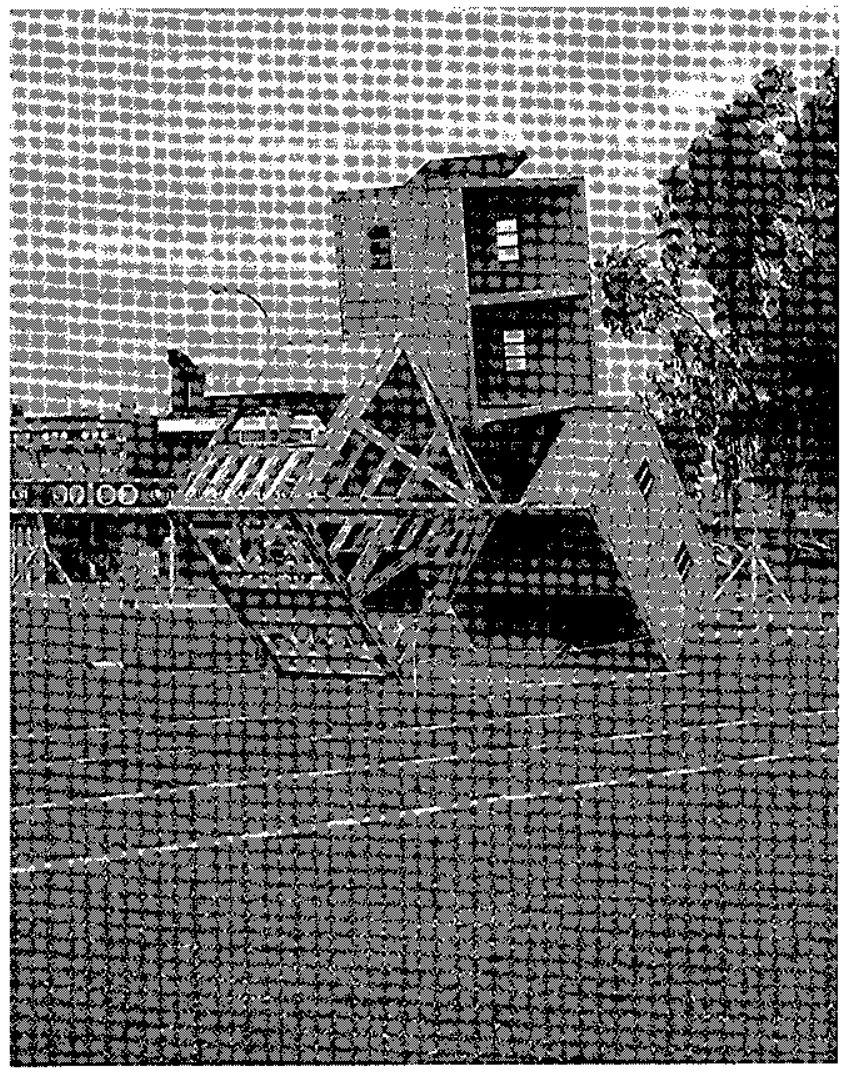

three children remain disappeared and it is their memory Aizenberg evokes through his trio of geometric figures. Aizenberg's was also the last to be erected: donated posthumously by his grandchildren, the son and daughter of the disappeared José and Valeria Beláustegui, it was installed in the park in 2003, two years after Oppenheim's and Tucker's.

As a set, the three sculptures in some ways harmonize with the principles behind the monument carved into the earth. Their moder $n$ aesthetics convey a certain restraint in representation and encourage a variety of readings, creating confined spaces that are never theless not completely closed in. As Tucker explains, Victory reflects the horror of state terrorism and also the hope of its victims: "the very fact that it is incomplete alludes to the victims truncated by terror; the strength and resistance of the shape "suggests both the cour age of the victims and the restitution over time of decor um and justice." Inspired by the works of Franz Kafka, Tucker began the series to which Victory belongs in the seventies as part of an attempt to translate into the language of modernist sculpture the fear and suffering of that time; built in the early eighties, the pieces were exhibited in New York and I ondon before the possibility of locating them definitively in Argentina arose (Comisión Pro Monumento a las Víctimas del Terrorismo de Estado, Escultura 637). Oppenheim's winning project reflects the themes of liberation and escape through its re-creation of a mechanism of imprisonment that can no longer imprison (490). In keeping with the countermonument tradition, Oppenheim emphasizes the role of each spectator in generating the work's meaning: "In defying its pur pose, the for ms are liberated and become pure art, pure statement in service only of their ability to inspire meaning" Aizenberg's exercise in witnessing, also the most personal, conforms like the other two to a principle of abstraction. The contours of his group portrait, rendered in giant silhouettes, 
"encierran un vacío que señala la ausencia de los cuerpos pero, al mismo tiempo, marcan su imborrable presencia" 'enclose an emptiness that signals the absence of bodies but, at the same time, marks their indelible presence' (Comisión Pro Monumento a las Víctimas del Terrorismo de Estado, Parque). The stature and strength of these bronze figures structure the horizon, an effect that their fragmentation simultaneously mitigates.

And yet, despite sharing some of the aesthetic preoccupations of the counter monument tradition, the sculptures deviate from it in significant ways. Although they could be described as "felicitously minimalist," these are not disappearing or invisible pieces; ranging between four and seven meter in height, they are not lacking in monumental ambition. Their presence on the Plaza de Acceso grants them a gatekeeping quality, while their imposing ver ticality, solidity, and size compete with the monumental cut, the power of its negative statement While all works of art ate inter pretive and themselves open to mul-

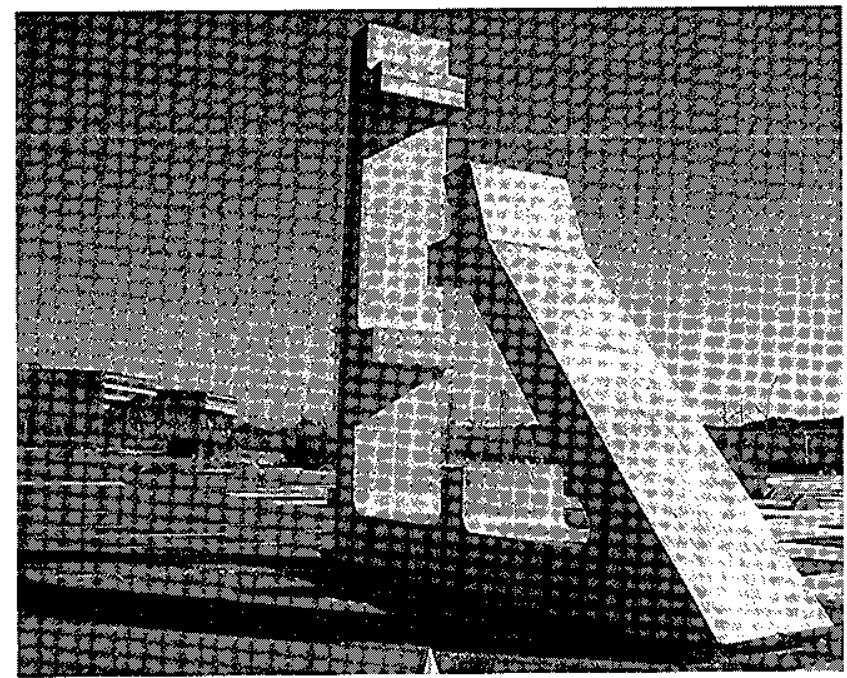

tiple inter pretations, these massive sculptures, as Nelly Richard argues in a different context, seem to "congelar el símbolo en un bloque conmemorativo sin fisuras que reifica el pasado ... [corriendo] el riesgo de proyectar la imagen estática de un pasado detenido" 'freeze the symbol in a commemorative block-with no fissures--that reifies the past

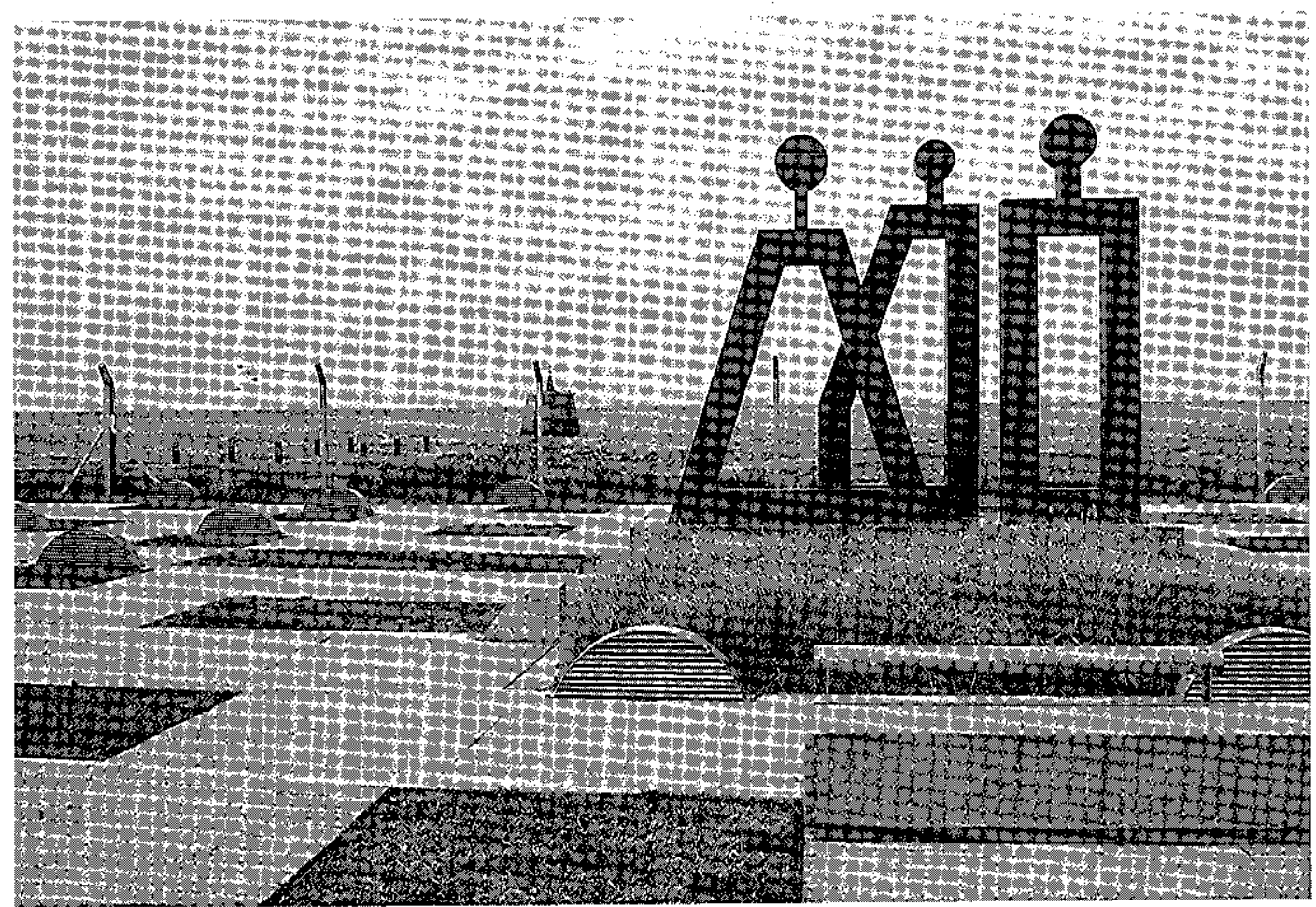

FIG. 3

Victoria (Victory) by William Tucker in the Parque de la Memoria Photo by John Cipperly

FiG. 4

Sin titulo (Untitled), by Roberto Aizenberg in the Parque de la Memoria 
running the risk of projecting the static image of a fixed past' (48-49). Instead of encouraging the kind of active aesthetic experience Battiti calls for, "un ámbito propicio para socavar certidumbres e inaugurar nuevos espacios de reflexión" "a propitious site for undermining cer tainty and inaugur ating new spaces for reflection' (59), their extraotdinary size (and their very titles, in the case of Monumento al escape and Victoria) implies a certainty in the passage to a new world order that has been established and fixed, once and for all, on the ruins of the dictatorship.

These sculptures, in short, risk overwhelming the spirit of the monument, aestheticizing memory in a way that interr upts the process of reflection that the cut in the ear th, the barten landscape surrounding it, and the monument's location generate. If the site incor porates the countermonument principles described by Young, in its current configuration the group of sculptures on the Plaza de Acceso disrupts that space for reflection, filling the void left by the abuses of state power with images that rise like phallic symbols, signposts in this theater organizing the staging of memory and its experience for the spectator. While it remains to be seen how the multisculptural section of the park will function as a whole once the other works are incorporated, the reified and didactic effect of its threshold as it now stands produces an unsettling cognitive dissonance in what is other wise a compelling work of recollection.

One way to interpret the puzzling coexistence of the sculptures and the monument is to refer back to the context of the park's creation in 1998. Its planning coincided with extensive media coverage of testimonials and documentaries regarding the dictator ship, part of what Claudia Feld has xeferred to as a memory "boom" that lasted three years (1995-98) Beyond the newfound commercial viability of those memories, however, there was then still little consensus regarding those memories. Argentina's institutions had not yet collapsed, the Due Obedience and Punto Final laws had not been declared unconstitutional by the high court, and those responsible for torture, death, and disappear ance not only remained free, having been amnestied by the then president, Carlos Menem, but also found themselves in the limelight, adding their confessional narratives to those of their victims in what proved a lucrative media circus The decision to construct both a monument and a sculpture park in this context is not surptising, given the high stakes of that memory boom; the use of reflective words and images of the fallen to guide recollection could indeed diminish the 1 isk of visitors' arriving at the wrong conclusions.. ${ }^{11}$ Sharing space with the monument's sobering gestuxe, the sculptures could not only hail spectators in a variety of ways but fur ther lend the park equilibrium Finally, they could prove effective mediums for granting official recognition to those groups that worked against forgetting in the postdictatorship period, as the inclusion of the Carteles de la memoria 'Memory Signs' by Grupo de Ar te Callejero suggests

While these rationales help explain the coexistence of the sculptures and monument, however, they cannot explain away the tension between them. In effect, it would have been almost impossible for the city legislature to foresee, at the proposal stage, how the grand sweep of the sculptures' gestures would offset the countermonument's refusal to narrate a definitive version of the past And yet, paradoxically, in the end this very shortsightedness could prove the park's greatest triumph. Rather than read their clash (sculptures-monument) as evidence of a failure in planning or design, I submit that, at least in their current state, it is the cacophony they gener ate together, the uneasiness their juxtaposition produces, that encourages the articulation of new memory discourses. In other words, what ultimately makes the park a magisterial rendering of memory work is the breach between the kinds of recollection 
the multisculptural complex and the monument represent-not simply because there is strength in multiplicity but also because it is in the distance between the two that the possibility for dissident narratives lies It is in the discomfort their contradictory inclusion elicits that an active, changing memory is being crafted. If we read the park's overall design, then, as a reflection of the unresolved issues that have continuously haunted Argentina's attempts to narxate its recent past-and that publicly play themselves out through official attempts to institutionalize memory-the park's incomplete and fissured vocabularies begin to appear (Richard 48). While signposts, sculptures that guide particular interpretations, can disr upt personal reflection, their presence can simultaneously serve as a reminder of all that was at stake for its creators in the articulation of that past This uneasy cohabitation, of the cut in the earth retreating into negative space and the images that aestheticize the memory debate, finally proves indicative of those very conflicts, conflicts most effectively figured in the metaphoric distance between the sculpture complex and the monument, between these divergent for ms of recollection

\section{Club Atlético: Epic Monument or Allegorical Ruin?}

Allegorization takes place when that which is most familiar reveals itself as (an)other, when the most customary is interpreted as a ruin, and the pile of past catastrophes hither to concealed under that storm called "progress" at last begins to be unearthed

-Idelber Avelax, The Untimely Present (233)

The site occupied during the first years of the dictatorship by the clandestine detention center known as Club Atlético has become, in the process of its excavation, a different kind of memory park. Located where the freeway at the Paseo Colón access ramp now stands, the Atlético functioned as a tor ture chamber dur- ing 1976 and 1977; approximately eighteen hundred victims were detained there before the construction of the Autopista 25 de Mayo shut it down, burying the cells and the criminal evidence they contained. ${ }^{12}$ Most of its prisoners were transported to other detention center's before disappearing like the building that had held them captive. On 13 April 2002, after persistent attempts by survivors and human rights groups to mark the site in some way, the city government of Buenos Aires began unearthing the history covered up by the freeway (fig. 5) The archaeological site has since been tr ansformed into a makeshift park: in addition to the excavation work, there are plants, benches imprinted with the estimated total number of disappeared and the admonition not to forget, a path where the names of repressors associated with the Atlético are engraved, a series of murals, and a sculpture constructed around one of the highway pillars by the Grupo Tótem (fig. 6).

Although its history contrasts with that of the Parque de la Memoria, the recollection the Atlético performs also contests institutional forgetting It is a place where conflicting memories erupt, where the will of the dictatorship-and subsequently of democratic regimes under neoliberal transition-to bury its violence under a discourse of progress is undone by the will of its victims to recall their trauma and to map it onto the city's facades. Evoking a set of tensions different from those surfacing at the edge of the Río de la Plata, then, the Atlético foregrounds local solutions to a national and global dilemma, inflecting the notion of progress in a globalizing world with meanings defined through community initiatives and civilian solidarity networks

If at the Parque de la Memoria the debates over commemoration took place largely behind closed doors, in the legislative meetings that culminated in its establishment, here they took the form of street warfare, through the insistent reappropriation and marking of territory. Elizabeth Jelin and Susana Kaufman 


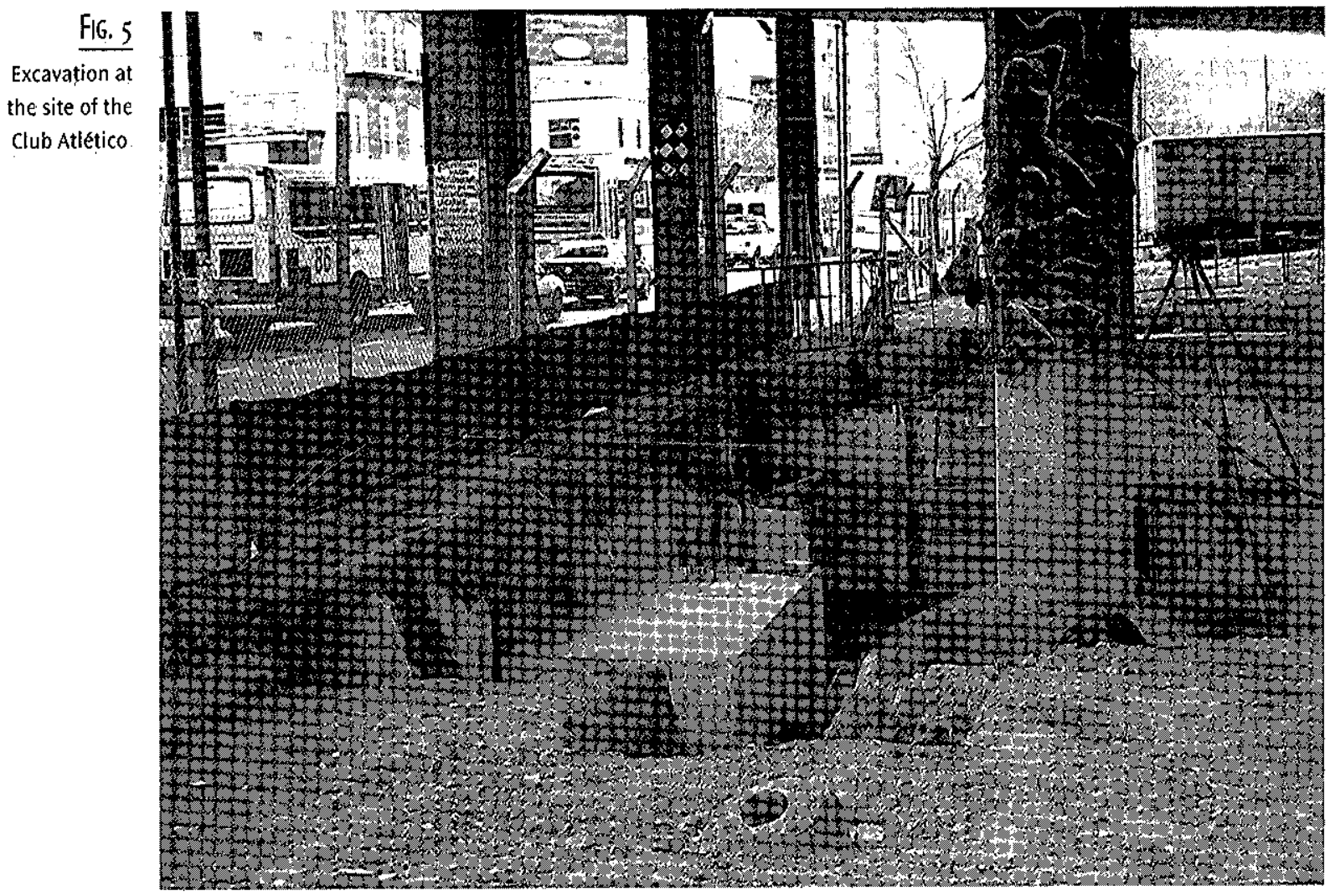

describe the struggle to lay claim to the site by survivors, human xights organizations, and neighborhood assemblies:

[I]n July 1996, close to 500 people participated in a gathering that included the construction of a papier maché structure of a tree and a public reminder with the faces of victims of repression. On that first occasion, a firebomb placed at night destroyed the tree and the memorial On the second Jornada de la memoria [Aug 1997], a plaque remembering the disappeared was set up, the names of the repressors were engraved, and during the commemoration a monument, a "totem," was collectively constructed on one of the pillars of the highway During the following night, the plaque was destroyed, the totem was torn down and the engr aved names of the repressors were covered with paint.

(97-98)

While most traces of these early commemotation attempts are no longer visible or have been replaced by more durable markers-the totem was reconstructed, poems and murals decorate the highway pillars, repressors' names are engraved in concrete, and benches invite reflection on the in tefutable evidence the excavation provides - the site nevertheless resists the temptation to reify the past. In contrast to the monumentalism of the Parque de la Memoria and its global reach, the Atlético speaks in more subdued tones, as if the voices of the disappeared were finding their way out of a tomb to vie for interpretive power. There have been no inter national competitions to select sculptures for the site or to choose designs for its commemorative architecture; its artworks are the result of grassroots organizing, not of institutional consensus. Perhaps because of this, what is there appears raw, not (yet?) "subjected to the flattening gloss of the maxket, the so-called waning of affect that has been identified with the times" (Masiello 13). Challenging the neoliberal mantra first 


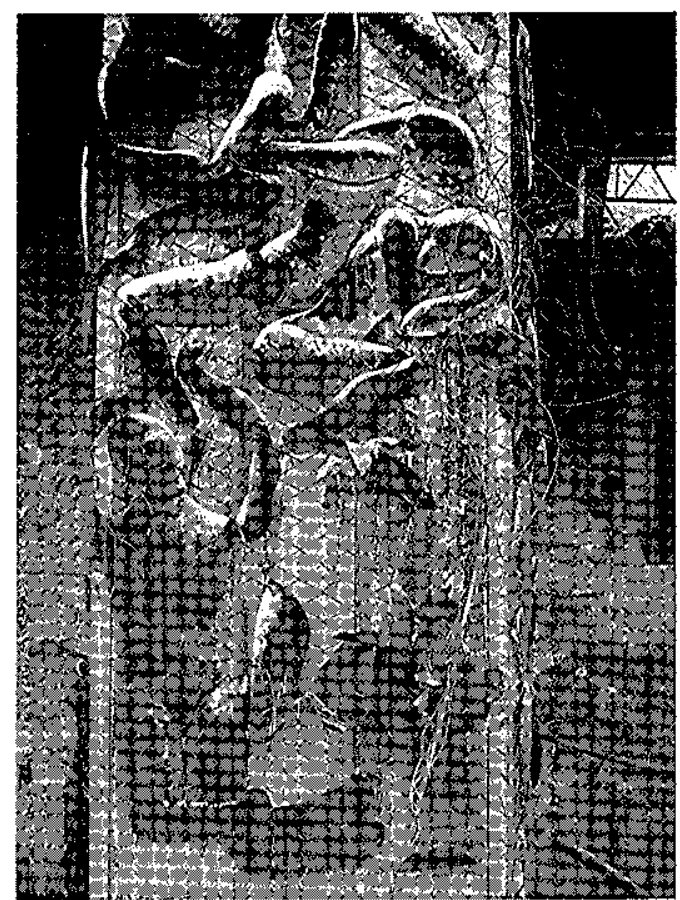

articulated by the military junta in the name of Western, Christian civilization and progress-and sustained thereafter by elected offcials-it quietly calls into question the values promoted by market-driven economies ${ }^{13}$ If Idelber Avelar is correct when he claims that it was "the dictator ship that made the transit from State to Market, a transit euphemistically designated as 'modernization'" (59), the site of the Atlético exposes the price paid by the social body for that transit simply by juxtaposing an emblem of "development"-the autopista - to the ruins and cadavers left in its wake.

Instead of vanishing in the urban jungle, the site hails visitors who stumble on it in the midst of the banality of city living. Like the totem wrapped in human forms climbing toward the freeway, this memorial ground appears to have sprouted from a crack in the sidewalk, breaking through the edifice of dictatorship to claim a life of its own. Disrupting the traffic of ordinary life, it intercepts the transit of citizens going about their business and urges them to pause; it marks a "new memory [walk] through the city" that can "help [them] resist and subvert the alltoo-programmed and enveloping messages of . ... consumer culture" (Boyer 28-29). Here the voices of the victimized speak the colloquial language of the streets through the poetry of Mar io Benedetti and Juan Gelman and through images painted on the freeway's pillars that represent various scenes of human suffering under torture (figs. 7 and 8). On one column, a line from Gelman reads, "Bajate un poco, contemplá esto que soy, este $\mathrm{za}$ pato roto, esta angustia, este estómago vacío, esta ciudad sin pan para mis dientes" "Come down a little, tegard what I am, this broken shoe, this anguish, this empty stomach, this city without bread for my teeth 'Distressing as these words and images are, their human scale and emphasis on the quotidian invite passersby to draw near, to seize the moment for reflection before it vanishes like the murals, graffiti, and ruins, all subject to decay. The benches silently await visitors, while the faded names of repressors, some already illegible, remind them of the precariousness of

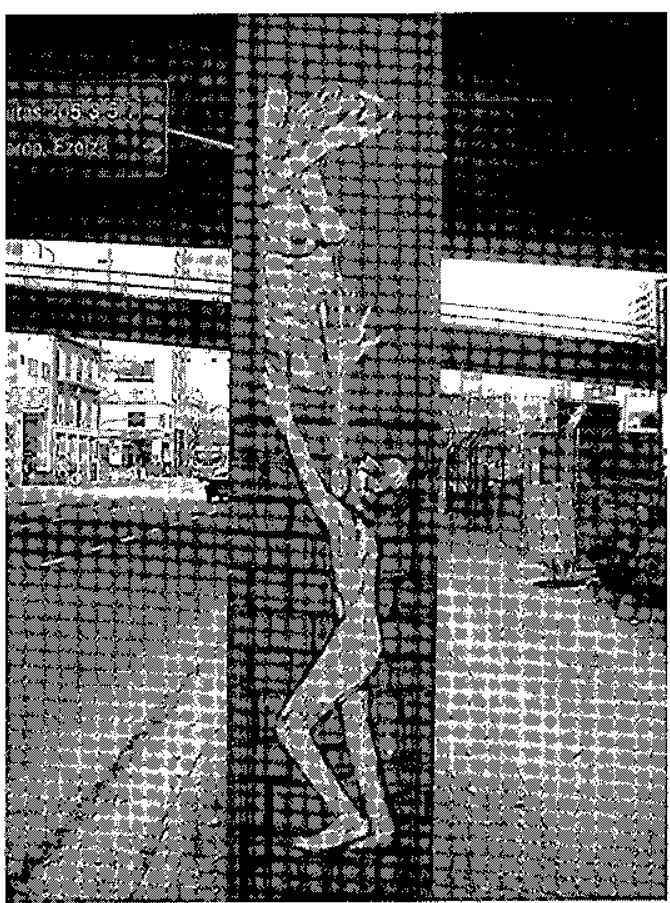

FiG. 6

Sculpture on a highway pillar at the site of the Club Atletico by the Grupo Tótem

FIG. 7

Painting on a highway pillar at the site of the Club Atlético Photo by John Cipperly 


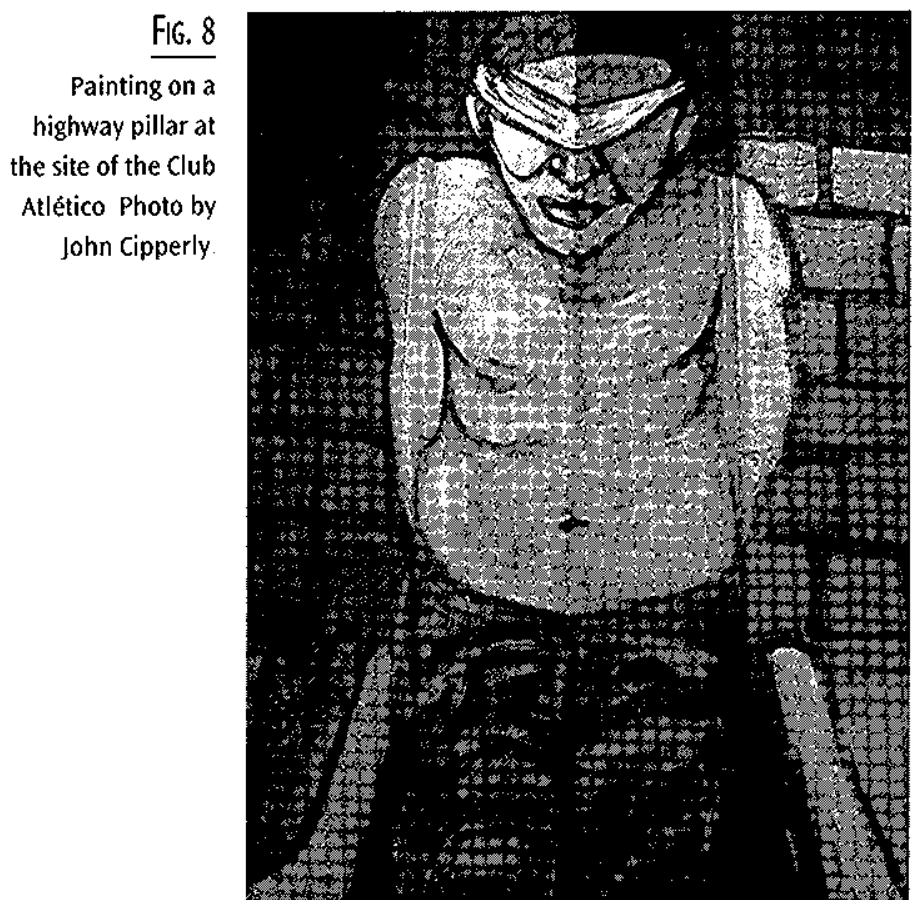

justice Underscoring the fragility of the past, their imper manence adds another layer to the Atlético's staging of memory, reminding beholders that justice and democracy are ongoing projects and that this work of recollection will have to be restored or reconfigured by future generations. I iterally and metaphorically, the site opens a wound that bears witness to the process of recovery (by the team of forensic anthropologists) and the reconstruction of memory as something inconclusive and imperfect; the space it circumscribes thus sets the scene for bridging past and present, for bringing survivors together, and for reinvigor ating the kinds of civilian solidarity networks the dictator ship destroyed ${ }^{14}$

If "the labor of mourning has much to do with the erection of an exterior tomb where the brutal literalization of the internal tomb can be metaphorized," this work becomes increasingly urgent in the face of "a transnational political and economic order [that] repeatedly reaffir ms its interest in blocking the advance of postdictatorial mourning work-as the digging of the past may stand in the way of the accumulation of capital in the present" (Avelar 9). The excavation of the Atlético reiterates the social, political, and institutional costs of not digging up that past, of not coming to terms with the foundational legacy of a regime that left Argentina in tatters Limited in scope and eschewing global ambitions, the site relies on the local chatacter of its interventions to remind its visitors that the $\mathrm{r}$ uins of this horror remain very much within Argentina and that it will be up to each of the country's citizens to settle these old accounts, to keep these memories alive, and to mourn and bury all the dead. At the same time, the Atlético denounces one of the languages of globalization-that of marketdriven economies that tur $n$ all citizens into consumers, liberating goods while preventing the free circulation of people-also associated with the global ambitions of the Parque de la Memoria Globalization need not be synonymous exclusively with free-market policies and privatization schemes that enrich the few and impoverish the majority. In Argentina, as the Parque de la Memoria reminds us, it can evoke the global influence of human $r$ ights organizations, of international courts, and of transnational solidar ity movements. It remains to be seen which of its potentials will help to define Argentina's future, whether the universal language of human rights will prove more compelling than the programs advocated under the banner of economic freedom or whether a balance between the two might be achieved The Atlético's eloquent staging of memory suggests, however, that Argentina's future hinges on the extent to which the nation can move beyond the global interests inscribed in its legacy of terror to grasp the languages of the local: the voices of the piqueteros and asambleistas denouncing the effects of global capitalism on their everyday lives; the murals and structures erected by human rights groups and neighborhood assemblies recalling human suffering; and the graffiti on city walls calling for justice and change.." 
Postscript: The Museo de la MemoriaEstablishing a New Foundation

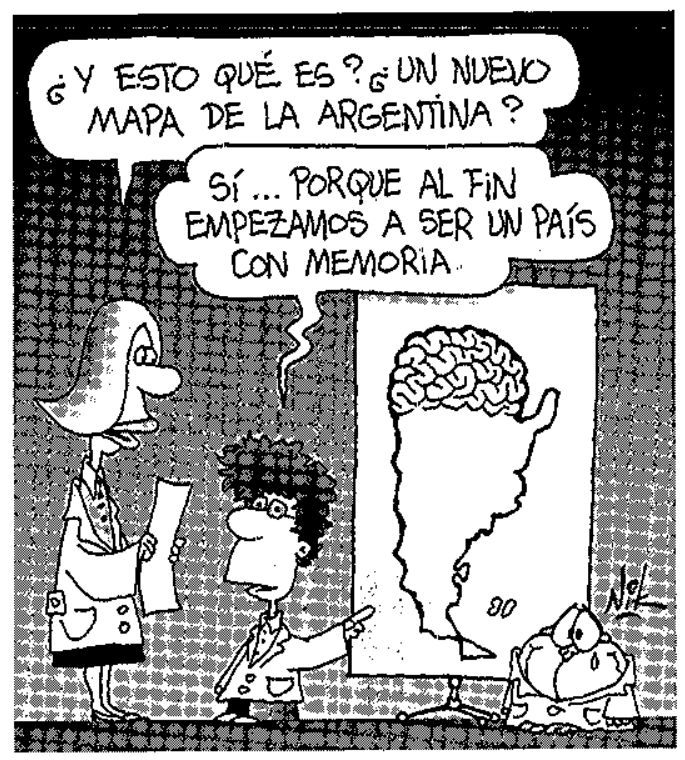

I would like to close with a reflection on the symbolism behind President Néstor Kirchner's decree that on the twenty-eighth anniversary of the coup transfor med the Navy Mechanics' School (ESMA) into a memory museum, one of the most significant inaugu$r$ al acts of his presidency. If the creation of a memory park and the transfor mation of sites like the Atlético bear the potential to change the city-and the concepts of citizenship it inscribes-the appropriation of the ESMA constitutes a seismic shift, striking a decisive blow to the authoritarian apparatus responsible for the nation's most recent genocide It establishes the state's responsibility for crimes against humanity and removes the military from the symbolic center of the nation, deterritorializing its power When the ESMA ceases to be an outpost of the military and is returned to the people who once ceded their land to it, this site of memory will signal that the rule of law has prevailed over unconstitutional initiatives, a decisive step in the mapping of a new Argentine cartography

While the shape the museum eventually will take remains open to debate, the act that brought it into being on $24 \mathrm{March} 2004$ and the media coverage of the ceremony provide rich materials for reflection As Federico Lorenz has pointed out, there is no mistaking the "vocación fundacional" "foundational vocation' behind the carefully choreographed event (22). If the weeks preceding it occasioned the retirement of four generals in protest and the objections of human rights groups to the participation of Peronist governors viewed as complicit with past and present human rights abuses, the day itself brought over forty thousand people to the ESMA to witness the vindication of, according to the president's carefully worded speech, "la generación que creyó y que sigue creyendo .... que este país se puede cambiar" "the generation that believed and that continues to believe that this country can be changed.." In a quarter century, it was the first time a nationally televised public act memorialized not only the victims of the genocide but also the activism of the militant generation decimated in clandestine concentration camps like the ESMA, and it represented yet another attempt, this time by the state, officially to lay to rest the two-demons theory promoted by the military to justify its "dirty war."

Earlier that day, human rights organizations had hung banners with hundreds of photographs of the disappeared on the ESMA's gates-a gesture that coincided almost exactly with President Kirchner's removal of the portraits of Generals Videla and Bignone, two of the ex-commanders of the military junta, from their place of honor at the Colegio Militar. The symbolic impact of these acts cannot be overemphasized; after all, these generals were the architects of the attempt to obliterate all ideological opposition. The figurative foregrounding of the identities of the desaparecidos through their photographic trace and simultaneous displacing-not erasing-of those of the generals underscored the triumph of the archive and the repertoire over the politics of terror. ${ }^{18}$ These gestures signaled the restructuring of the social order
"What is this? A new map of Argentina?" "Yes

because finally we are becoming a country with memory. Cartoon by Cristian Dzwonik 
through the establishment of a new political contract in which human rights, justice, and memory vanquished impunity and forgetting Overtaking the fences surrounding the navy complex, the banners with photographs of the victims challenged its gatekeeping function while redrawing its perimeter and bringing to the fore the violence that had long been kept hidden in the recesses of the camp

The inside-outside dialectic evident in the removal of the portraits at one site (inside the Colegio Militar) and the placement of the banners at another (on the periphery of the ESMA) played itself out in other ways, too The planners of the ceremony, which was at first to take place inside the gates of the ESMA, moved it to the street to defuse tensions over who should attend; making it a public act, a gover nment representative clarified, meant that all those who wanted to participate could and that the president need not extend special invitations or exer this veto power over potential attendees. The official event began at one in the afternoon when Anibal Ibarra, mayor of Buenos Aires, and President Kirchner signed the memory museum into existence The gates of the ESMA were then opened to the public, allowing hundreds of people to enter the site for the first time and the commemorative part of the ceremony to continue on a stage located on a side street. ${ }^{19}$

Without minimizing the symbolic weight of the commemorative event, I will focus here on the inside-outside tension manifest in the movement of people at the site Most obviously, this tension was resolved by the massive influx of people onto the grounds of the ESMA, once heavily policed, and into the buildings that had housed the clandestine detention center: Gaining access on this anniversary meant, for ordinary civilians, not only confix ming the existence of the camp but also reclaiming a piece of history official voices had for too long denied The destruction and writing on walls that took place once the gates had been opened obeyed a similar logic The graffiti-_"Milicos asesinos" 'military assassins,' "nunca más" 'never again,' and "fábrica tomada" 'factory taken over' (Polack 7)-were not products of senseless vandalism but rather part of a coherent effor $t$ to assert a memory discourse still in the making and about which Argentines have yet to reach consensus ${ }^{20}$ Never again ( $i n u n c a$ más!) would these politically conscious actors allow the military to assassinate those it had been sworn to protect What is more, by taking back Argentina's most impor tant military establishment, they were explicitly affiliating themselves with other groups mobilizing to take back the nation's promise. Their use of the phrase fábrica tomada inscribed the preeminence not only of civil rights, through the occupation of the ESMA, but also of the human rights of the workers who, in the wake of the economic collapse, refused to sit idly by as their factories closed down, their parts sold to the highest bidder, leaving massive unemployment in their wake. ${ }^{21}$ Scripting a different story and asser ting their claims for representation, the people at the ESMA voiced their solidarity with the occupied-factory movement to suggest that together they could rebuild Argentina.

Perhaps even more interesting than these reterritorializing gestures are the ways in which the media repor ted the events, underscoring all that remains at stake in these struggles for interpretive power. While the more conservative daily, La nación, played up what it depicted as mass vandalism (Polack), the left's Página/12 refer red to the graffiti as "algunas pintadas" 'some markings' (Ginzberg) and stressed the festive atmosphere in which the national anthem had been sung in a show of solidarity between the living and the dead ${ }^{22}$ As it turns out, and as $L a$ nación later reported, roughly thirty individuals out of forty thousand attendees were responsible for the vandalism that occurred ("Intentan" 14). In other words, La nación's strategic choice to underscore the violence bears further examination, since the paper just as easily might have commented on other, equally notewor thy behaviors of the crowd 
The latter was the strategy chosen by Página/12, whose coverage emphasized a peaceful and orderly occupation by individuals moved to tears in "un momento de descarga dentro del lugar que, hasta no hace mucho, fue el campo de concentración más grande de Sudamérica" 'a moment of emotional release inside the place that, until not long ago, was the largest concentr ation camp in South America." Minimizing the vandalism, Página/12 summed up the day by noting, "Los manifestantes volvieron a entrat a la ESMA, recorrieron el parque, entraron al Casino de Oficiales, cantaron el himno en el salón central del edificio principal, tiraron papelitos e hicier on algunas pintadas" "The demonstrators entered the ESMA again, scoured the grounds, entered the officers' casino, sang the national anthem in the main building's central room, scattered some papers, and made some markings'-cer tainly not actions worthy of alarming headlines. Its proclaimed simply, "I a verdad es la libertad absoluta" "Truth is absolute freedom,' suggesting that the act at the ESMA promised to yield that tr uth by dragging the past out from the shadows (Ginzberg). This strategic accounting is echoed in the opinion piece published in Página/12 by Rodolfo Walsh's widow, Lilia Ferreyra, the day following the act ${ }^{23}$ In her version, "El Presidente abrió las rejas de la Esma y, pasado el tumulto inicial, un río silencioso de padres, abuelos, hijos, jóvenes, hombres y mujeres trazó por primera vez un curso sinuoso entre los jardines y edificios de lo que fue uno de los principales centros clandestinos de detención de la Dictadura Militar" 'The president opened the gates to the ESMA, and, following the initial tumult, a silent stream of parents, grandparents, sons, youth, men, and women traced for the first time a sinuous path between the gardens and buildings of what had once been one of the dictator ship's principal clandestine detention centers." This was a "multitud [que] marchaba sin gritos ni festejos; caminaba sin prisa, en respetuoso silencio, mirando a un lado y al otro, imaginando quizás el día en que allí llevaron al hijo, al nieto, al padre, a la madre, al esposo, y los desaparecieron para siempre" 'multitude [that] marched without cries or celebration; it walked without hurry, in a respectful silence, looking this way and that, imagining perhaps the day that their son, grandchild, father, mother, husband were taken there and disappeared forever.' And, according to Ferx eyra, it was a breakthrough made possible by "la fuerza inclaudicable de la memoria colectiva" "the unfaltering force of collective memory' on a day "de luminosa justicia" 'of luminous justice."

In contrast, a charactex istic headline in $\mathrm{La}$ nación, "El Espacio de la Memoria se estrenó con destrozos y robos" "The Space of Memory Debuted with Vandalism and Looting,' highlighted the more disruptive aspects of the site's occupation Citing a comment made by two adolescents who witnessed the destruction, the note following the headline evoked a much oldex discourse in Argentine history, that of the struggle between civilization and barbar ism: "Se supone que éste es un espacio para la tolerancia y resulta que lo primero que hacemos es romper todo, robar cosas y pintar las paredes Al final nos van a decir que somos más intoler antes que los militares" "This is supposed to be a space for toler ance and the first thing we do is break everything, steal things, and paint the walls. In the end they'll say we're more intolerant than the military' (Polack) Resuscitating the two-demons theory, the note suggests an equivalence between crimes against humanity and the "barbaric" behavior of the masses, behavior potentially marking them as more intolerant than the military. It is a discourse echoed in other Nación ar ticles and opinion pieces, as the editorial published that Sunday makes clear:

Se insiste en concentrat todas las culpas sobre el sector militar y se ocultan, en cambio, las gravísimas responsabilidades de los guerrilleros, terror istas, políticos, periodistas, 
intelectuales, educadores y aun religiosos que menospreciarion con sus actos o con sus prédicas el sagrado valor de la vida humana Cabe preguntarse si no se está programando otra vez a los jóvenes para per petrar crímenes violentos con la excusa de estar sirviendo a un ideal revolucionario. ("Mirar" 28)

All the blame is insistently heaped on the military, while the grave responsibility of the terrorist guerrillas, politicians, journalists, intellectuals, educators, and even religious figures who belittled with their behavior or their sermons the sacred value of human life remains hidden It seems fitting to ask if the young are not once again being programmed to perpetuate violent crimes with the excuse of serving a revolutionary ideal

This evocation of the two-demons theory, followed by the suggestion that commemorations of this sort set the stage for social protest and violence to come, cannot be deemed innocent. In a climate in which the national anthem's refrain "libertad, libertad, liber tad" 'freedom' has been supplanted in mass mobilizations by "seguridad, seguridad, segur idad" 'security,' many worry that the issue of human rights will once again lose ground to the call for a return to the hard-line policies of the dictator ship. ${ }^{24}$ It is the climate of insecurity following the $2001 \mathrm{crisis}$, then, that along with inspiring antiestablishment solidarity movements also reinvigor ates a theory long discredited by scholars and human rights activists. And it is this str uggle to define the legacy of militancy that we see played out in the symbolic enactments surrounding the creation of a memory museum.

And yet, despite the tensions evident in these struggles to define the past, the significance of the ESMA's takeover cannot be overstated. It represents a changing of the guard, a shift from a government of complicity to one in which the once-silenced victims occupy center stage The redr awing of the physical and symbolic landscape through the establishment of this memory site suggests that, as Juan Gelman beautifully put it, once again "the sky's limits have changed" (91). But now this site of memory is full of "bodies embracing / giving shelter consolation and sadness / .... and who raise up their heart on fire / like a nation of people blowing kisses" (92). The occupation of the ESMA, the realignment of this map, means that the compañeros banished somewhere else might finally find their way back home to a place of rest in the heart of the nation. This is a victory for them, and for all those who fought for truth and justice, two elements fundamental to any democratic reconciliation.

These events are foundational. If, as Gustavo Remedi argues, "la arquitectura de la ciudad es realmente un mecanismo de almacenamiento de conceptos, valores, normas, instrucciones y memorias, así como un mecanismo cognitivo que nos orienta y nos lleva de la mano, automáticamente, sin tener que tomar conciencia de esa programación almacenada" 'a city's architecture is really a mechanism of storing concepts, values, norms, instructions, and memories and simultaneously a cognitive mechanism that orients us and takes us by the hand automatically, without making us conscious of that stored programming' (349), the Buenos Aires of the twenty-first century is poised to instruct its inhabitants in a new kind of civility ${ }^{25}$ Initiatives like the museum, the excavation site, and the memory park have begun to reshape the city's contours; they represent attempts through grassroots organizing to reappropriate the nation's promise, a promise expressed in the str uggles for social justice violently repressed nearly three decades ago. While it is not always clear who for ms part of these collective projects, it is clear that the crimes of the authoritarian state have again taken center stage. The past is always present, but todaybecause of such projects-it is consciously made so, helping to rebuild the institutional foundations of a democracy deeply wounded by the military and underscoring the importance of safeguarding univer sal human rights in a world undergoing massive economic re- 
structuring As citizens navigate this changing world, the city emerging from the ruins of dictator ship will lead them to repeat a new mantra-one grounded in the inalienable human rights of each of its people While some might despair that the new memorials may one day become invisible, I propose that they will do so only when the tensions urban interventions inscribe no longer interpellate citizens working toward change. Indeed, if citizens in the practice of everyday life are "automatically" drawn into more representative and empowering patterns of sociability, the authoritarianism mar ring Argentina's recent history stands a chance of becoming definitively past. This hope is a beginning.

\section{NOTES}

I am grateful to Sandra Raggio and Diego Diaz at the Comisión Provincial por la Memoria and to my students and colleagues at the College of William and Mary, for their critical feedback in the writing of this piece

1. All translations following the Spanish are my own; I have omitted the Spanish original where published English translations exist.

2. Alfredo Pucciarelli makes explicit the link between Argentinas 2001 collapse and policies initiated under dictatorship For a more detailed periodization see Gabriela Cerruti s history of memory"

3 Impor tant works on postdictatorship cultural production in Argentina include Iiempo pasado: Cultura de la memoria y giro subjetivo (Sarlo:2005), The Art of Transition (Masiello, 2001): The Untimely Present (Avelar: 1999), A Lexicon of Yerror (Feitlowitz, 1998), Disappearing Acts (Iaylor, 1997) and Memoria colectiva y políticas de olvido (Bergero and Reati 1997) On memory in postdictatorship societies, see the series edited by Elizabeth Jelin and published by Siglo veintiuno

4 Interventions carried out by H.I J OS Madres and Abuelas de Plaza de Mayo, Memoria Abierta, Grupo de Arte Callejero, Escombros, Etcétera and Grupo Tótem are exemplary here

5 Diana Iaylor's work on $\mathrm{H} I$ ) O S. (2003 [Archive]), Claudia Kozak's on graffiti (2004), and Fernando Reati's on 'el monumento de papel" 'paper monument' (2004) reflect this impor tant shift

6. L aw 46 of the Buenos Aires legislature establishes the site for the memorial park and outlines the param. eters for its construction. My reading is based on the approved design, which to date remains unfinished.

7. After much debate regarding which names to include on the thirty thousand plaques, the legislature limited commemoration to those individuals assassinated between 1970 and 1983 and to those who remain missing; some plaques were left blank, to be filled in as more victims are identified. Left out are those who suffered under state repression before 1970 , were freed from clandestine detention centers or were exiled (Vecchioli 90)

8 Made up of legislators, human rights activists, and University of Buenos Aires representatives, the planning commission was also established by I aw 46 .

9. The six invited artists are Roberto Aizenberg, Juan Carlos Distéfano, Norber to Gómez, I eo Vinci, Jenny Holzer, and Magdalena Abakanowicz. Half of the sculptures are by Argentine artists

$10 \mathrm{I}$ am invoking here Huyssen s concept of artist as secondary witness (16)

11 Worth noting along these lines are Claudia Fontes's sculpture of the youngest desaparecido, who was taken at the age of fourteen Jenny Holzer's phrases carved into benches, and Marie Orensanz s sculpture consisting of a text written in cement or stone. where one must seek the composition of the sentence inscribed in the void" (Orensanz)

12. According to Nunca más approximately fifteen hundred people passed through the Atlético (Comisión Nacional sobre la Desaparición de Personas 158) The larger figure appears on information posted at the excavation site

13. Francine Masiello's discussion of cultural responses to neoliberalism is helpful here: "If neoliberalism, as a celebration of tree-marketeering, paints a sheen of apparent neutrality on social contradiction. erasing strands of memory that bound individuals to their past and suppressing discussion of 'value, literature and art [and sites like the Atlético] instead cultivate tension, revealing the conflicts between an unresolved past and present, between invisibility and exposure, showing the dualities of face and mask that leave their trace on identitarian struggles today" (3)

14. Since the excavation project began, ex-detainees and relatives of the disappeared have met at the Atlético on Thursdays at four oclock to share information Presumably: in addition to enabling commemorative acts: the intention behind the facility planned for the Parque de la Memoria is also to encourage these types of informal gatherings.

15 Piqueteros refers to unemployed workers, literally "picketers," whose protests helped bring De la Ruas regime to an end; approximately twenty-five died and more were wounded in a violent repression between 19 and $20 \mathrm{Dec}$ 2001. In addition to organizing massive demonstrations to protest their lack of work, piqueteros use roadblocks that interr upt the flow of goods and people to call attention to their situation Asambleas refers to neighborhood assemblies 
whose collective presence in 2001 and public interventions in recent years have helped transform the cityscape.

16 Highlights of the event were captured on film by Pagina/12 and distributed under the title ESMA: Museo de la Memoria (2004)

17. Broadly propounded by the military during the transition to democracy, the theory claimed that the regime was forced to act like a "demon" - conducting clandestine operations in a "dirty war" - to counter a worse demon, militant groups whose terrorist actions endangered national security.

18 As Diana Iaylor elaborates these concepts in The Archive and the Repertoire, the archive represents memory materialized as "documents, maps, literary texts, letters, archaeological remains: bones: videos, films, CDs, all those items supposedly resistant to change," like the ID photos (19) But it is the "repertoire [that] enacts embod. ied memory: performances: gestures, orality: movement, dance, singing-in short, all those acts usually thought of as ephemeral, nonreproducible knowledge" (20) In the creation of the memory museum, we see these working "in tandem and . alongside other systems of transmission, confirming Iaylor s observation that "the archive and the reper toire exist in a constant state of interaction" (21)

19 The commemoration included the reading of a poem by Ana Maria Ponce, a disappeared militant; speeches by members of H I J.OS, Ibarra, and Kirchner; and performances by León Gieco, Joan Manuel Sexrat, and Víctor Heredia

20 Other tactics involved the burning of a military effigy: the installation of a sculpture of a Ford Falcon crushed by a coat hanger, the removal of a sign that read Long Live the Navy" (Galak), art actions by the group Etcétera (in which a young man disguised as Videla stuck his head through a frame and called out. Return the painting, alluding to the portrait that had been taken from the Colegio Militar shortly before it was to be xemoved by Kirchner), and the laying of red carnations in. side the ESMA's gates (Ginzberg)

21. I am grateful to Victoria Ruetalo for pointing out the double import of this gloss For more on the occupied-factory movement that emerged after Argentina's economic collapse, see Avi L.ewis and Naomi Klein's documentary, The Take (2004)

22 While La nación remains Argentina's more conservative paper: Página/12 has become since Kirchners election a primary medium for disseminating the govexnment's views This shift in the paper's role (from antiestablishment to vocero oficial 'official voice') is reflected in the reporting analyzed here

23 A writer, journalist, and leading intellectual figure, Rodolfo Walsh was assassinated in a military ambush on 25 March 1977, the same day he sent his open letter to the military junta protesting its human rights record His bullet-riddled body was last seen at the ESMA. and it remains disappeared
24. The substitution of the refrain in the national anthem occurred in connection with the well-known case of Axel Blumberg, a young engineering student, whose kidnapping and murder moved thousands in Argentina to demand greater security In April 2004, only days after the twenty-eighth anniversary of the coup, his father led a mobilization before Congress, where he presented a petition with five million signatures demanding stricter penalties for crimes and an investigation into corruption in the police force of larger Buenos Aires. While Blumberg initially gax nered a huge following, most human rights organizations agree that his movement constitutes a dangerous and slippery slopé. Jorge Balán's commentary regarding cultures of fear seems apropos here: 'Fear is now as much a threat to democracy as violence itself, since it may again justify repression, emergency policies that circumvent the constitutional rule and more broadly, alienation from the democratic political process" (5)

25. Remedi is drawing on Angel Rama's observation in L a ciudad letrada that "la ciudad dicta todo lo que uno debe pensar, lo fuerza a uno a repetir su discurso" the city dictates everything one must think forces one to repeat its discourse' (Remedi 349).

\section{WORKS CITED}

"Art, Memory and Reflection." Parque de la Memoria Comisión Pro Monumento a las Victimas del Ierrorismo de Estado 23 Aug $2006<$ http://www parquedelamemoria org ar/parque-ing/index htm> Path: Sculptural Projects

Avelar, Idclber. The Untimely Present: Postdictatorial I atin American Fiction and the Task of Mourning. Durham: Duke UP, 1999

Balán Jorge Introduction Citizens of Fear: Urban Violence in Iatin America Ed Susana Rotker New Brunswick: Rutgers UP, 2002 1-6

Battiti, Florencia "El arte tiene la palabra." Puentes 39 (2003): 56-59

Bergero, Adriana, and Fernando Reati, eds Memoria colectiva y políticas de olvido Argentina y Uruguay, 1970-1990 Rosario: Viterbo 1997.

Boyer, M Christine The City of Collective Memory: Its Historical Imagery and Architectural Entertainments Cambridge: MII P, 1994

Brodsky. Marcelo Nexo Buenos Aires: La Marca, 2001

Cerruti, Gabriela "Ia historia de la memoria." Puentes 13 (2001): 14-25.

Comisión Nacional sobre la Desaparicion de Personas. Nunca más: Informe de la Comisión Nacional sobre la Desaparición de Personas. 16th ed. Buenos Aires: Eudeba, 1991

Comisión Pro Monumento a las Víctimas del T'etrorismo de Estado Escultura y memoria 665 proyectos presentados al concurso en homenaje a los detenidos desaparecidos y asesinados por el terrorismo de estado en 
la Argentina Buenos Aires: Editorial Univer sitaria de Buenos Aires, 2000

Parque de la Memoria. Ira etapa: Plaza de Acceso Buenos Aires: Gobierno de la Ciudad de Buenos Aires, n.d

ESMA: Museo de la Memoria Prod Román lejtman Videocassette Página/12:2004

Feitlowitz, Marguerite A L exicon of Terror: Argentina and the I gacies of Torture New York: Oxford UP, 1998

Feld, Claudia Del estrado a la pantalla: I as imágenes del juicio a los ex comandantes en Argentina Madrid: Siglo Veintiuno de España; Social Science Research Council, 2002

Ferreyra. Lilia "Cada día" Pagina/12 25 Mar 2004 24 Oct $2006<$ http://www pagina12 com ar/diario/ elpais/1-33241-2004-03-25 html >

Galak, Oliver "Una jor nada de gestos simbólicos y emociones. "I a nación 25 Max 2004: 6

Gelman, Juan Unthinkable Tenderness: Selected Poems Ed and trans yoan Iindgren Berkeley: $U$ of California $P$ : 1997 91-92

Ginzberg, Victoria "La verdad es la libertad absoluta " $P a ́-$ gina/12 25 Mar. 2004 24 Oct $2006<$ http://www pagina12 com ar/diario/elpais/1-33243-2004-03-25 html>

Huyssen, Andreas "El Parque de la Memoria: The Art and Politics of Memory" ReVista: Harvard Review of Iatin America (Winter 2001): 15-17

"Intentan identificar a los que dañaron la ESMA "I a nación 27 Mar 2004: 14

Jelin, Elizabeth Ios trabajos de la memoria Madrid: Siglo Veintiuno de España; Social Science Research Council 2002

Jelin, Elizabeth, and Susan Kaufman I Iayers of Memories: Twenty Years after in Argentina "The Politics of War Memory and Commemoration Ed I. G Ashplant, G Dawson, and M Roper London; Routledge: $200089-110$

Kozak, Claudia Contra la pared Sobre graffitis, pintadas $y$ otras intervenciones urbanas Buenos Aires: I ibros del Rojas, 2004

I ewis, Avi, and Naomi Klein, dirs. The Take Arna-Alper; Klein I ewis; Natl. Film Board of Canada; Canadian Broadcasting DVD. First Run / Icar us, 2004

I orenz, Federico. "Io que está en juego "Puentes 4.11 (2004): 20-22

Masiello, Francine The Art of Transition: Latin American Culture and Neo-liberal Crisis. Durham: Duke UP, 2001

"Mirar hacia el país de mañana" L a nación 28 Mar 2004: 28

Nora, Pierre Realms of Memory: Rethinking the French Past. Ed I awrence D. Kritzman Irans Arthur Goldhammer New York: Columbia UP, 1996
Oppenheim, Dennis "Monumento al escape / Monument to Escape " Parque de la Memoria Comisión Pro Monumento a las Victimas del Terrorismo de Estado 23 Aug $2006<h t t p: / / w w w$ parquedelamemoria org ar/parque-ing/ index htm> Path: Sculptural Projects; Information on the Artists and Their Works; Dennis Oppenheim

Orensanz, Marie "Pensar es un hecho revolucionario/ Thinking Is a Revolutionary Fact " Parque de la Memoria Comision Pro Monumento a las Víctimas del Terrorismo de Estado 23 Aug $2006<h t t p: / / w w w ~$ parquedelamemoria org ar/parque-ing/index htm $>$ Path: Sculptural Projects; Infor mation on the Artists and Their Works; Marie Orensanz

Polack Maria Elena "El Espacio de la Memoria se estrenó con destrozos y robos "I a nación 25 Mar 2004: 7

Pucciarelli, Alfredo R "Ceder la dama" Puentes 3.10 (2003): 10-14

Reati, Fernando El monumento de papel: I a construcción de una memoria colectiva en los recordatorios de los desaparecidos argentinos en Página/12 XXV Inter nacional Congreso of the I atin American Studies Assn I as Vegas. 9 Oct 2004

Remedi, Gustavo "I os lenguajes de la conciencia histórica: A propósito de Una ciudad sin memoria Bergero and Reati 345-69

Richard, Nelly "La mirada atenta "Puentes 39 (2003): 46-49

Sarlo, Beatriz Tiempo pasado: Cultura de la memoria y giro subjetivo Buenos Aires: Siglo XXI Editores Argentina 2005

Iaylor, Diana The Archive and the Repertoire: Performing Cultural Memory in the Americas Durham: Duke UP, 2003

- Disappearing Acts: Spectacles of Gender and $\mathrm{Na}$ tionalism in Argentina's "Dirty War. Durham: Duke UP, 1997

Iucker. William "Victoria/Victory" Parque de la Memoria Comisión Pro Monumento a las Víctimas del Yerrorismo de Estado 23 Aug $2006<$ http:/www parquedelamemoria org ar/parque-ing/index $h$ tm $>$ Path: Sculptural Projects; Infor mation on the Artists and Their Works; William Tucker

Vecchioli Virginia "Políticas de la memoria y formas de clasificación social ¿Quiénes son las 'Víctimas del Terrorismo de Estado en la Argentina? I a imposibilidad del olvido Recorridos de la memoria en Argentina, Chile y Uruguay Ed Bruno Groppo and Patricia Flier. La Plata: Al Margen, 2001 83-102

Vezzetti, Hugo "Scenes from the Crisis" Journal of Latin American Cultural Studies 11 (2002): 163-71

Young, James $\mathrm{E}$ At Memory's Edge: After-images of the Holocaust in Contemporary Art and Architecture. New Haven: Yale UP, 2000 